67. We dge Fi e 1 d の T P R, TAR筬便補正法 - Op e n F i e 1 dのデータを用いてー

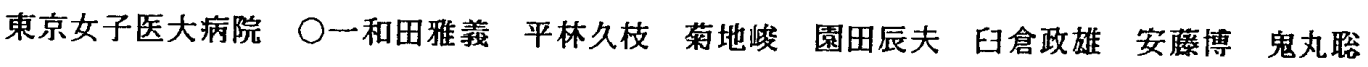

（目的）Wedge Filterを使用した場合、TPR, TAR は0pen Fieldと比較して差が生しるためWedge Field のTPR, TAR の 使用が望ましいと報告されている。Wedge Filterごとに全照射野についての测定、治療計画用コンピュータへのビー ムデータ入力等を考虑した場合困難である。そこで簡便に精度よく補正する方法を検討した。

(方运) 10MVX線，C0-60r線で0pen FieldとWedge Field のIPR, TAR を水ファントームを用いて電離箱で測定した。 照射野 $5 \times 5 \sim 15 \times 15 \mathrm{~cm}$ 、深さピーク深〜20 c m、Wedge Filterは $15^{\circ} \sim 60^{\circ}$ を使用した。Open FieldのIPR, TARに 各哚さのHedge Factorを乗した値と、Wedge Field のIPR, TAR にピーク媣のWedge Factorを乗した値を比較した。

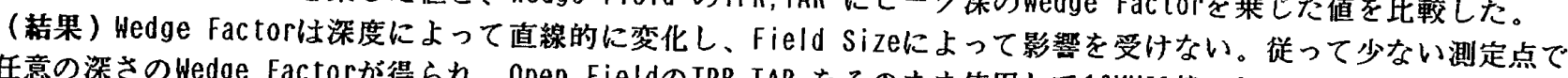
任意の深さのWedge Factorが得られ、Open FieldのIPR,TAR そのまま使用して10MVX線，C0-60r線において簡便に 精度よく補正することができた。

\title{
68. ビルドアップ領域の吸収線量测定の検討
}

\section{東京都立医癔技術短期大学 ○势藤秀敏 安部真治 福士政広 加藤 洋 小倉 泉}

高エネルギーX線および $r$ 線の表面およびビルドアッブ領域の吸収線量は、照射唗置の線筫、照射野の大きさ、コ リメータの材啠、構造やコリメーター表面間距離、シャドートレイやウェッジフィルタなどの使用によって変化する。 このような電子平衡にない領域の吸収線量の測定にはごく薄い空を持ち、電離箱の深さは線量の勾配の方向に十分浅 い線量計を使用しなければならない。しかし、使用する線量計の形状、材質が測定精度に大きく影警する。我々は外

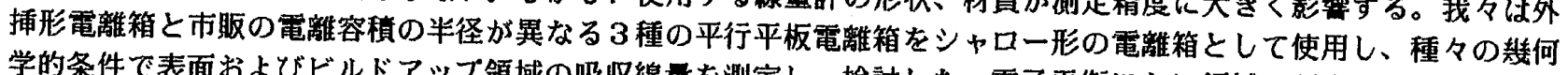
学的条件て表面およびビルドアッブ領域の吸収線量を测定し、検討した。電子平衡にない領域の测定には外抻形電離 箱が理想的であるが、测定に相当の時間、常力を要するので一般的ではない。また固定の電極間隔をもつ平行平板形 電離箱は一般に外括形電離箱の㑚定値より大きい值を示し、また電離容積の半径、保護電極の大きさなどで测定値に 差が生じた。ここではビルドアッブ領域の測定に必要な形状について検討し、報告する。

69. 軟組織等仙ファントム・タフウォーターと水ファントム、Mix一DPの光子ビーム線量測定に打㚈る比較

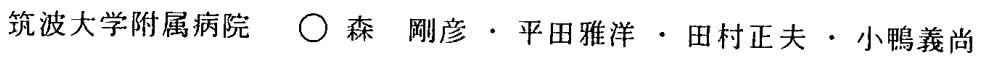

〔目的〕平岡らが新たに開発したェポキン樹脂を基本材料とした軟組織等侕フンントム・タフウォーター（WEー211）を、 光子ビームの線量测定に用いた場合の特性について、水ファントム、Mix-DPファントムと比較する。

[方法]タフウォーター、水ファントム、Mix-DPについて、同ーリファレンス線量計を用い、 ${ }^{\circ} \mathrm{Co} \cdot r$ 線、 $6 \mathrm{MVX}$ 線、 $10 \mathrm{MVX}$ 線、照射野 $5 \times 5 、 10 \times 10 、 20 \times 20 \mathrm{~cm}^{2}$ について、PDDを測定し、それらの差を求め、をた線量計の校正および
線量も文校正にそれらを用いた場合の差をむ求め、比較梌討した。

〔結果〕タフウォーターファントムと水ファントム、MixーDPファントムとのPDDの差は、照射野 $10 \times 10 \mathrm{~cm}^{2} 、$ 深さ $5 \mathrm{~cm}$ では、 ${ }^{60} \mathrm{Co} \cdot \gamma$ 線でそれでれー0.3\%、+0.3\%、6 MVX線で-0.2\%、+0.1\%、10MVX線で $-0.6 \% 、-0.4 \%$

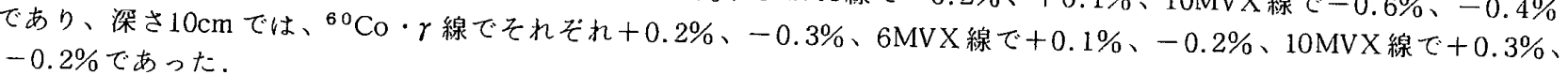

70. JARP 形線量計を用いた不均質フフントムでの線量测定の精度・再琴性（第2報）

$6 \mathrm{MVX}$ 線、10MVX 線に批㚈不均質領域での線量测定の再見性

筑波大学附属病院 ○森 剛彦・平田雅洋 · 田村正夫 · 小鴨義尚

〔目的〕第1報では、 ${ }^{60} \mathrm{Co} \cdot \gamma$ 線、3種類 $\left(\rho=0.20 、 0.28 、 0.42 \mathrm{~g} / \mathrm{cm}^{3}\right)$ の電子密度の 異なる肺フ ントムについての 線量测定の精度・再現性について報告したが、今回は、6MVX線、10MVX線に打けるJARS不均質慓集ファントム(近似) での、JARP形線量計を用いた場合の線量測定の再現性について恰討する。

〔方法〕JARS不均質標準ファントム (近似)（胸壁 $3 \mathrm{~cm} 、$ 肺 $15 \mathrm{~cm}\left(\rho=0.30 \mathrm{~g} / \mathrm{cm}^{3}\right)$ 、後胸壁 $10 \mathrm{~cm}$ )、同一Geometry での、a）絽り返し測定の变動伱数、b）時間の違いによる差（\%）、c）四季（月日）の違いによる差（\%）および、その

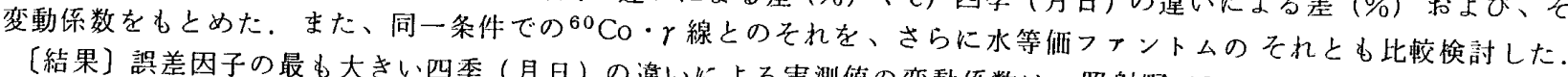

〔絬果〕誤差因子の最も大きい四乎（月日）の違いに上る実測値の変動倸数は、照射野 $10 \times 10 \mathrm{~cm}{ }^{2}$ について、不妁質

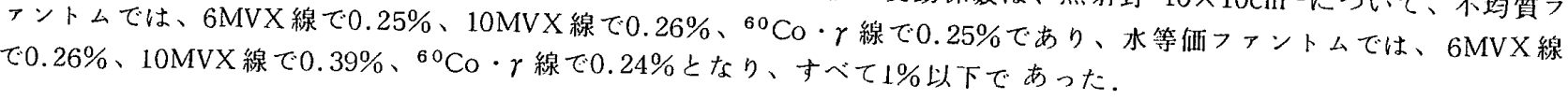

